\title{
Potential early indicators of anthropogenically derived nutrients: a multiscale stable isotope analysis
}

\author{
S. Vermeulen*, N. Sturaro, S. Gobert, J. M. Bouquegneau, G. Lepoint
}

MARE Centre, Laboratory of Oceanology, University of Liège, Sart Tilman B6c, 4000 Liège, Belgium

\begin{abstract}
Increasing human pressure along Mediterranean coastlines raises the need to define sensitive bioindicators that provide an early response to nutrient enrichment. We performed multiscale carbon and nitrogen stable isotope analyses on the limpet Patella caerulea, the snail Monodonta turbinata, epilithic biofilms, and the macroalga Rissoella verruculosa inhabiting the rocky midlittoral zone. Samples were seasonally collected in 2006 from 5 sites exposed to a range of anthropogenic discharges in the Revellata Bay area and in Marseille harbour (France). All bioindicators exhibited strongly elevated $\delta^{15} \mathrm{~N}$ values at impacted sites compared to pristine ones, which revealed the biological availability of anthropogenically derived nutrients. Only epilithic biofilms tended to show both the occurrence of nutrient pulses during the tourist season and a $\delta^{13} \mathrm{C}$ response at impacted sites. In contrast to macroalgae, which exhibited a somewhat equivocal signal, gastropods and especially M. turbinata provided the best time-integrated picture of the graduated exposure of the 5 sites to anthropogenic impact. Results also showed first evidence of large isotopic variability at a scale of tens of metres, close to that found at the kilometre scale. The intra- and interspecific isotopic variability in gastropods may be explained by the patchiness of resources and specific morphological and behavioural features, but these factors do not greatly hamper their potential as early bioindicators of wastewater disturbances.
\end{abstract}

KEY WORDS: NW Mediterranean · Stable isotopes · Eutrophication · Gastropods · Biofilms · Macroalgae $\cdot$ Patchiness

Resale or republication not permitted without written consent of the publisher

\section{INTRODUCTION}

Eutrophication is considered to be one of the main threats to marine coastal ecosystems. Among other deleterious effects, this process involves changes in the functioning of ecosystems, leading to negative socioeconomic impacts (Nixon 1995, Cloern 2001). The naturally nutrient-limited Mediterranean Sea is thought to be highly vulnerable even to low anthropogenic nutrient inputs (UNEP/FAO/WHO 1996). Although there is a wealth of evidence of drastic shifts in macrophyte communities following long-term exposure to high nutrient loads in the Adriatic Sea (Munda 1993) and along Spanish and French coastlines (Soltan et al. 2001, Pinedo et al. 2007), changes due to low anthropogenic discharges are less conspicuous because they are usually confounded with the effects of natural disturbances
(Cloern 2001). Early detection of nutrient enrichment is required in order to prevent further degradation of aquatic habitats. However, initial effects are likely to be missed if measurements are restricted to physicochemical water properties (e.g. nutrient concentrations, salinity, plume dispersion) and community compositions, as these are known to vary greatly in time and space (e.g. Carballo et al. 1996). Moreover, these analyses do not provide evidence of an uptake of sewage matter by biomasses (Costanzo et al. 2001). Such difficulties may be overcome by using indicator organisms which integrate pollution signals in their tissues and reflect the quality of the habitat in which they live (Oehlmann \& Schulte-Oehlmann 2003).

One method that can detect these signals is stable isotope analysis. This application is based on the fact that nitrogen originating from human effluents (e.g. 
high trophic level faecal material) has a typically ${ }^{15} \mathrm{~N}$-enriched isotopic composition compared to naturally occurring dissolved inorganic nitrogen (DIN) and that both sources differ isotopically and are available at the base of food webs. These allochtonous nutrients also undergo a fractionation process towards ${ }^{15} \mathrm{~N}$ enriched values through both the preferential loss of ${ }^{14} \mathrm{~N}$ isotope during ammonia volatilization and the bacterial enzymatic affinity for ${ }^{14} \mathrm{~N}$ during degradation (McClelland et al. 1997, Costanzo et al. 2001). Stable carbon isotope ratios are a useful means to identify consumers' food sources (DeNiro \& Epstein 1978) and to determine the terrestrial or marine origin of organic matter (Fry \& Sherr 1984). Moreover, as nutrient enrichment exerts bottom-up forces at the base of food webs, the carbon isotopic values of microalgal assemblages can reveal changes in physiological states (Brutemark et al. 2009), biodiversity (Vuorio et al. 2006) and thus in the food sources available to consumers (Vadeboncoeur et al. 2003, Gil et al. 2006).

Numerous studies have successfully detected, quantified and traced the biological availability of wastewater-derived nutrients in marine food webs (Tewfik et al. 2005, Armitage \& Fourqurean 2009), even under relatively low nutrient discharges (McClelland et al. 1997). However, some of these took samples from a single point and at one spatial scale and/or did not specify the spacing of samples collected from pristine and impacted sites (Riera et al. 2000, Waldron et al. 2001). This could have some confounding effects in detecting pollution impact (i.e. over- or underestimation of the spatial extent of the impact), especially when using low-mobility invertebrate grazers as potential indicators, because of the natural spatial heterogeneity of their habitat and of the uneven influence of contaminants in the environment (Bishop et al. 2002). Another potential source of confusion is the intra- and inter-specific variability of the signals delivered by bioindicators (e.g. morphological and behavioural features). Such analysis is required in order to validate and facilitate their routine use in the context of future monitoring schemes (Segar et al. 1987).

Due to negligible tidal amplitude, the Mediterranean midlittoral zone is an easily accessible area where biota is directly exposed to human activities (Soltan et al. 2001). The endemic prosobranch gastropods, the limpet Patella caerulea (Linnaeus, 1758) and the snail Monodonta turbinata (Born 1780), are among the most frequently encountered consumers of this narrow rocky fringe. These long-lived species are accessible all-year round and often present where mussels, a frequently used bioindicator, are not. Limpets and snails are coexisting microphagous grazers known to feed on epilithic and epiphytic biofilms which are ubiquitous structures composed of bacteria, microalgae, macroalgal sporelings, protozoans, and detritus (Steneck \& Watling 1982, Burns \& Ryder 2001, Staal et al. 2007). Although it is known that biofilms can play a key role in fuelling freshwater food webs (Vadeboncoeur et al. 2003), their marine counterparts are still poorly investigated, probably because of sampling difficulties and a lack of knowledge regarding their taxonomic compositions (Hill \& Hawkins 1991). Nevertheless, biofilms could be a major pathway of anthropogenically derived material towards upper trophic levels (Burns \& Ryder 2001). The endemic red foliose macroalga Rissoella verruculosa (Agardh 1849) is another emblematic species of the Mediterranean midlittoral zone, where it forms well-developed belts (Pérès \& Picard 1964). These organisms and assemblages exhibit features of good potential bioindicators, being of limited mobility or sedentary, abundant, and easy to identify (Oehlmann \& Schulte-Oehlmann 2003). They belong to different trophic levels and exhibit 2 nutrient incorporation paths, with biofilms and macroalgae taking nutrients from the surrounding water and gastropods relying essentially on microflora. Furthermore, they presumably have different turnover rates and thus could provide differentiated temporal information about anthropogenic impacts.

In the present study, multi-spatial scales and seasonal dual $\mathrm{C}$ and $\mathrm{N}$ stable isotope analyses were performed on gastropods, epilithic biofilms, and macroalgae collected from rocky midlittoral areas exposed to a range of anthropogenically derived nutrients in order to (1) assess their sensitivity and verify their use as early indicators of eutrophication; (2) validate the use of gastropods as bioindicators by analysis of their intraand inter-specific isotopic variability.

\section{MATERIALS AND METHODS}

Study area. This study was conducted in the midlittoral zone of the Revellata Bay area (northwest Corsica, France) and of Marseille harbour (southern France) (Fig. 1). Due to negligible tidal range (about $40 \mathrm{~cm}$ ), the midlittoral zone is restricted to a narrow fringe located at the air-sea interface and experiences high variability of environmental factors (Pérès \& Picard 1964). The waters of Revellata Bay are oligotrophic, and primary production mainly relies upon $\mathrm{NH}_{4}{ }^{+}$recycling (Velimirov \& Walenta-Simon 1992). Rainfall is typical of the Mediterranean climate (i.e. sporadic and seasonal) and results in intermittent river flows and runoff which supply very limited amounts of nutrients. As neither agricultural nor industrial activity is present, the main sources of allochthonous nutrients are (1) the occasional entrance of deep nutrient-rich waters driven by NNE winds, favouring early spring 


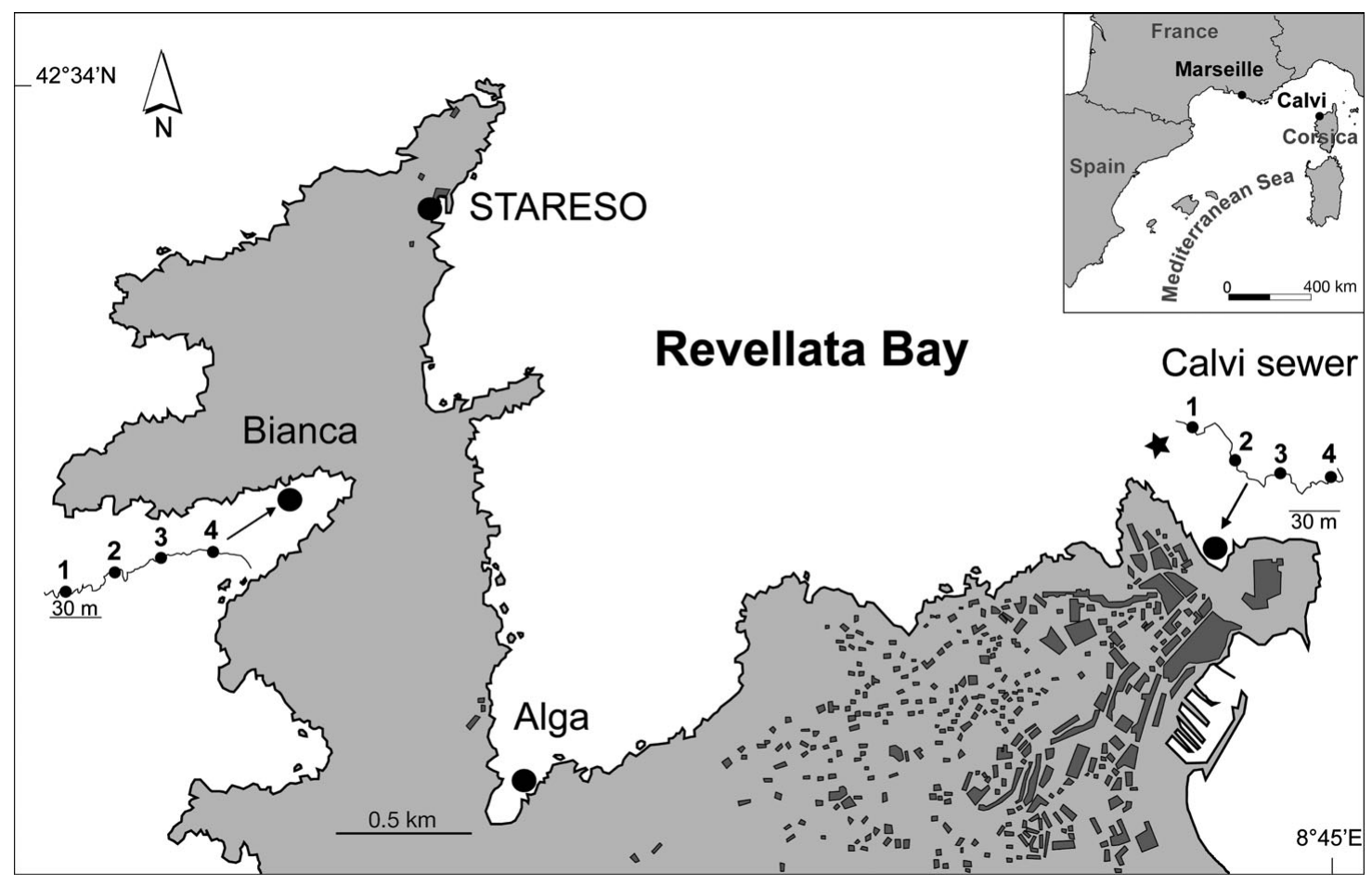

Fig. 1. Location of study areas. Inset shows Calvi (Corsica) and Marseille harbour; the main map shows the sites in Revellata Bay (Alga, STARESO, Calvi sewer), its vicinity (Bianca) and midlittoral small-scale sampling points (1 to 4) along near sea-surface level horizontal transects. $\star$ : sewage outfall; $30 \mathrm{~m}$ : distance between points on transects; dark grey shading: built-up area of Calvi

phytoplankton blooms (Skliris et al. 2001) and, (2) domestic wastewaters that undergo a physicochemical treatment before being discharged at $36 \mathrm{~m}$ depth (Fig. 1). The amount of nutrients discharged into the bay (mainly $\mathrm{NH}_{4}{ }^{+}$and $\mathrm{PO}_{4}{ }^{3-}$ ) is very low most of the year but reaches a maximum in summer (i.e. when waters are ultra-oligotrophic) due to tourism, which results in a 10-fold increase in the local population of about 5000 people. Average amounts of discharged Kjeldahl nitrogen (organic and ammoniacal forms) and total phosphorus (organic and mineral forms) ranged respectively from 53 to $536 \mathrm{~kg} \mathrm{~d}^{-1}$ and from 2 to $5 \mathrm{~kg}$ $\mathrm{d}^{-1}$ in December 2005 and July 2006 (Compagnie Méditerranéenne d'Exploitation des Services des Eaux, pers. comm. 2006). The Marseille area is densely urbanized and is inhabited by about 1.5 million people. The fishing and leisure harbour (1450 moorings) continuously receives organic and wastewater loads from diffuse sources (Ifremer 2007).

Sample collection and processing. Samples were seasonally and randomly handpicked on granite substrata over a distance of $10 \mathrm{~m}$ in February (winter), June (summer) and November (autumn) 2006. A largescale (kilometre) sampling was carried out according to the 'control vs. impacted' status of 4 sites located in Revellata Bay and its vicinity (Fig. 1). We chose 2 con- trol sites (Alga, Bianca), a moderately impacted one (STAtion de REcherche Sous marine et Océanographique [STARESO], which is locally influenced by septic tank discharges) and an impacted one (Calvi sewer). Additionally, samples from Marseille harbour were collected in winter and summer, allowing for comparison with a heavily and continuously impacted site. Small-scale sampling was conducted in autumn at points 30 metres apart along horizontal transects at Bianca and Calvi sewer (Fig. 1). Points were numbered from 1 to 4 so that cumulative distances between extreme points were $90 \mathrm{~m}$. Only the most frequently sampled points over seasons were included in the overall spatial and temporal analyses of data (i.e. point 1 for Bianca, 4 for Calvi sewer).

Samples of epilithic biofilms were collected with a toothbrush over $100 \mathrm{~cm}^{2}$ areas. Biofilms were apparently growing in the same set of environmental conditions, e.g. light and wave exposure. The red macroalga Rissoella verruculosa, which forms seasonal belts at the sea surface level, was collected in summer. Six replicates of Patella caerulea and Monodonta turbinata were collected, where and when available, together with biofilms from the same location. Due to logistical constraints, we were not able to perform sampling at Marseille harbour in autumn. Shell metrics were 
recorded using a calliper $(\sim 0.1 \mathrm{~mm})$ and we were careful to select individuals within a narrow size range for analysis: shell length $25-30 \mathrm{~mm}$ for $P$. caerulea and shell height $10-15 \mathrm{~mm}$ for $M$. turbinata. Additionally, we investigated the size-related variability of data among 26 individuals of $P$. caerulea ranging from 11 to $37 \mathrm{~mm}$ in shell length at STARESO in autumn.

Pedal muscles of gastropods were isolated under a binocular microscope and the sex of Patella caerulea individuals was determined (Orton et al. 1956). In the size range defined for snails Monodonta turbinata, individuals did not reach sexual maturity, like their Atlantic counterparts M. lineata (Crothers 1994). Samples of epilithic biofilms were centrifuged and rinsed with MilliQ water ( 3 times at $1880 \times g$ for $10 \mathrm{~min}$ ) and exposed to fuming $\mathrm{HCl} 37 \%$ in order to remove salts and inorganic carbonates, respectively. The use of this gentle acidification procedure avoids loss of acid-soluble organic matter (Hedges \& Stern 1984). Epiphytes were scraped from Rissoella verruculosa with a razor blade. Samples were then oven-dried at $50^{\circ} \mathrm{C}$ for $48 \mathrm{~h}$ and ground into a homogeneous fine powder using mortar and pestle.

Stable isotope and elemental content analyses. Measurements were performed with a mass spectrometer (Optima, Micromass) coupled to a CNS elemental analyzer (Carlo Erba). Isotopic ratios were computed in $\delta$ values $(\%)$. Data were expressed relative to the Vienna Pee Dee Belemnite standard (vPDB) and to atmospheric $\mathrm{N}_{2}$ for carbon and nitrogen respectively. Reference materials from the International Atomic Energy Agency (IAEA) were N1 (ammonium sulphate, $\delta^{15} \mathrm{~N}=0.4 \pm 0.2 \%$ ) and $\mathrm{CH} 6$ (sucrose, $\delta^{13} \mathrm{C}=-10.4 \pm$ $0.2 \%$ ). The analytical precision based on the standard deviation of a gastropod muscle replicate was $0.3 \%$ for carbon and $0.2 \%$ for nitrogen.

Statistics. Spatial and interspecific differences in isotopic compositions as well as an interaction term (Site $\times$ Species) were tested using the Scheirer-Ray-Hare nonparametric 2-way ANOVA following the procedure recommended by Zar (1984) and Dytham (2003). As this technique was restricted to balanced sample designs, tests were performed on gastropod isotopic data from the Revellata Bay area over the 3 seasons. Further spatial and temporal multivariate data analyses were conducted using matrices of normalized Euclidean distances calculated from $\delta^{15} \mathrm{~N}$ and $\delta^{13} \mathrm{C}$ values. Similarity matrices were analyzed using the nonparametric analysis of similarity (ANOSIM). Outputs of this randomization procedure are the $\mathrm{R}$ statistics, which provide an absolute measure of the degree of separation between groups, with values close to zero and unity showing complete similarity and discrimination respectively. Two-way crossed ANOSIM was performed to test for spatial (among sites) and temporal (among seasons) differences in $\delta^{15} \mathrm{~N}$ and $\delta^{13} \mathrm{C}$ values among gastropods, and to compare the interspecific isotopic patterns across seasons. Runs were first performed on $\delta^{13} \mathrm{C}$ and $\delta^{15} \mathrm{~N}$ values together (Global R) and then on each variable separately in order to determine their respective contribution to the betweengroup differences. The R statistics were also used for pairwise comparisons between sites. The small-scale data were analyzed using 1-way ANOSIM, considering each $30 \mathrm{~m}$-apart point as independent. This procedure was also employed to test for spatial differences among data from Rissoella verruculosa. In addition, nMDS (non-metric multidimensional scaling) ordination analyses graphically supported the results from ANOSIM. The stress values provided by nMDS indicate the goodness-of-fit of the representation of distances between samples in the 2-dimensional space of the ordination plot. A stress value below 0.05 is considered to provide an excellent picture of a matrix configuration. Multivariate analyses were completed using PRIMER v.6 software (Clarke \& Gorley 2006). The coefficients of variation, calculated by dividing the standard deviation by the mean (CV in \%), were provided and express a dispersion measure of the isotopic data.The potential size-related effect on isotopic values (Patella caerulea) and the intrapopulation isotopic variance were assessed using linear regressions (Statistica v.8, StatSoft 2007).

\section{RESULTS}

\section{Epilithic biofilms and macroalgae}

Results from epilithic biofilms showed high kilometre-scale and temporal variability, with large differences in carbon $\left(\Delta^{13} \mathrm{C}\right)$ and nitrogen $\left(\Delta^{15} \mathrm{~N}\right)$ isotopic values occurring between sites in winter $\left(\Delta^{13} \mathrm{C}=10.6 \%\right.$, $\left.\Delta \Delta^{15} \mathrm{~N}=6.7 \%\right)$ and across seasons $\left(\Delta^{13} \mathrm{C}=10.3 \%, \Delta^{15} \mathrm{~N}=\right.$ $3.2 \%$ ) (Table 1). The data from Marseille harbour and in summer for Calvi sewer showed some ${ }^{15} \mathrm{~N}$ and ${ }^{13} \mathrm{C}$-enriched values, contributing to their separation from other sites in the nMDS plot (Fig. 2a). This trend also appeared along the horizontal transect at Calvi sewer (Table 2) where the results showed some large variations of isotopic ratios over short distances. The $\mathrm{C}: \mathrm{N}$ contents of biofilms also exhibited an overall seasonal trend towards increasing values (i.e. lower $\mathrm{N}$ contents) from winter to autumn (Table 3).

The isotopic values of Rissoella verruculosa showed large spatial differences (Global $\mathrm{R}=0.66$ ) (Fig. 3a,b, Table 4). The most ${ }^{15} \mathrm{~N}$-enriched values occurred at Calvi sewer and provided, when compared to the data from STARESO and Bianca, a maximum $\Delta^{15} \mathrm{~N}$ range of $3.0 \%$ allowing a good discrimination between sites 


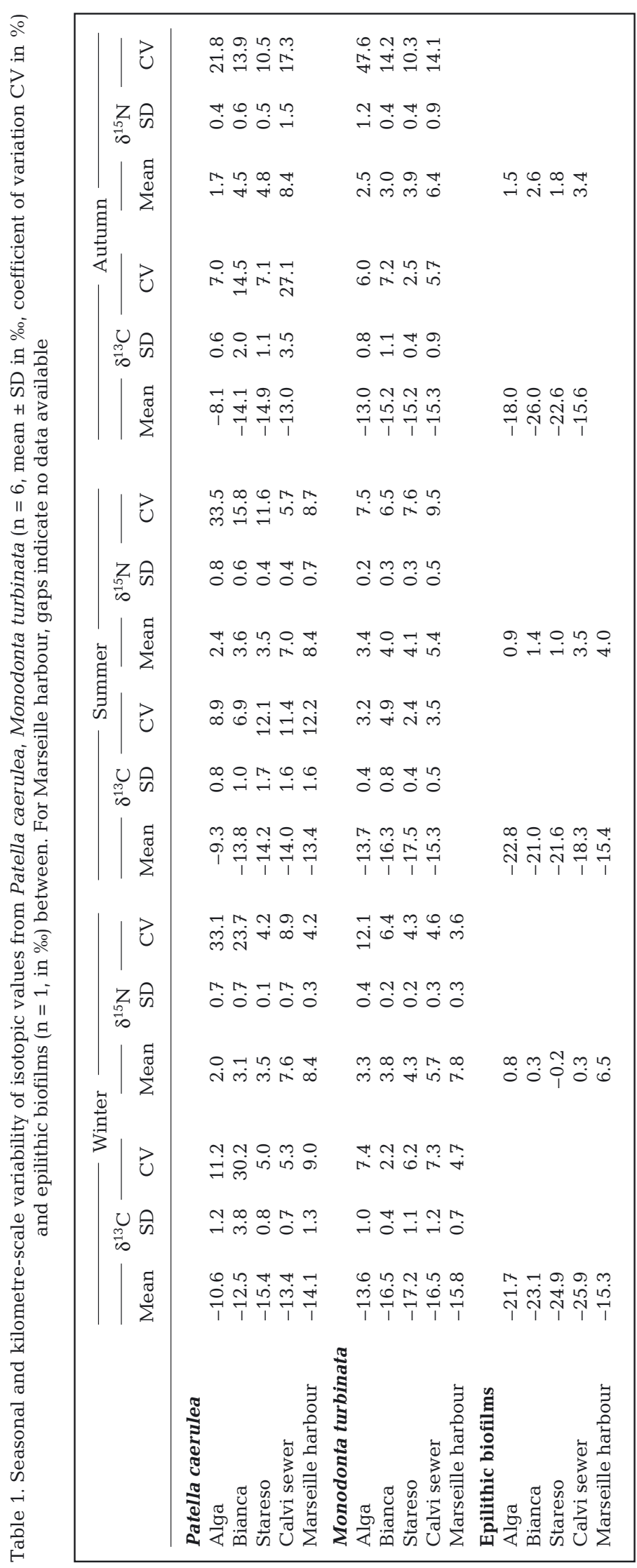

(Fig. 2b). The values from Alga were ${ }^{15} \mathrm{~N}$-enriched relative to those from Bianca and STARESO. Moreover, the lowest $\mathrm{N}$ contents $(0.9 \%$, Table 3$)$ along with the most ${ }^{13} \mathrm{C}$-depleted compositions clearly set $R$. verruculosa individuals from Alga apart from others (e.g. Alga vs. Bianca, $\mathrm{R} \delta^{13} \mathrm{C}=1$, Table 5).

\section{Gastropods}

The kilometre-scale variability of isotopic values was particularly high for both species (Global $\mathrm{R}=$ 0.72-0.78) compared to the seasonal variability (Global $\mathrm{R}=0.26-0.30$, Tables $1 \& 4$ ). The $\delta^{15} \mathrm{~N}$ values accounted for most of this spatial variability ( $R$ $\left.\delta^{15} \mathrm{~N}=0.72-0.76\right)$ so that the nMDS discriminated very well between sites (Fig. 2c,d) and allowed 3 clusters to be identified, from the most enriched to the most ${ }^{15} \mathrm{~N}$-depleted values: (1) Marseille harbour, Calvi sewer, (2) STARESO, Bianca (3) Alga (Fig. 3a). The results from ANOVA corroborated the occurrence of these high spatial differences $(p<0.0001)$. The largest differences of mean $\delta^{15} \mathrm{~N}$ values $\left(\Delta^{15} \mathrm{~N}\right)$ were consistently observed between Alga and Calvi sewer, with values ranging from 4.6 to $6.7 \%$ for Patella caerulea and from $2.0 \%$ to $3.9 \%$ for Monodonta turbinata in summer and autumn respectively. The data from Marseille harbour provided some close to maximum $\Delta^{15} \mathrm{~N}$ values for P. caerulea $\left(\Delta^{15} \mathrm{~N}=6.0\right.$ and $6.4 \%$ o) and a further extended range for $M$. turbinata $\left(\Delta^{15} \mathrm{~N}=\right.$ $4.5 \%$ ). As suggested by the nMDS plots (Fig. 2c,d), the $\Delta^{15} \mathrm{~N}$ values between Calvi sewer and Marseille harbour were more pronounced for M. turbinata $\left(\mathrm{R} \delta^{15} \mathrm{~N}=1\right)$ than for $P$. caerulea ( $\mathrm{R} \delta^{15} \mathrm{~N}=0.46$, Table 5). Moreover, only snails showed some ${ }^{15} \mathrm{~N}$-enriched values at STARESO compared to Bianca ( $\mathrm{R} \delta^{15} \mathrm{~N}=0.37$ ). The kilometre-scale variability of $\delta^{13} \mathrm{C}$ values was lower than the $\delta^{15} \mathrm{~N}$ variability $\left(\mathrm{R} \delta^{13} \mathrm{C}=0.41-0.48\right.$, Fig. $3 \mathrm{~b}$, Table 4). Spatial differences in $\delta^{13} \mathrm{C}$ values were also detected by the ANOVA ( $p<0.0001)$. For both species, the ${ }^{13} \mathrm{C}$-enriched compositions from Alga weighted in the observed spatial pattern and clearly set this site apart from others (Fig. 2c,d, Table 1). The maximum $\Delta^{13} \mathrm{C}$ values usually occurred between STARESO and Alga and ranged, according to season, from 4.8 to $6.8 \%$ for $P$. caerulea and from 2.3 to $3.8 \%$ for $M$. turbinata. There were no, or only slight, differences in $\delta^{13} \mathrm{C}$ values between Bianca, STARESO, Calvi sewer and Marseille harbour (Table 5).

The small-scale differences in isotopic values according to sampling points were particularly high, 

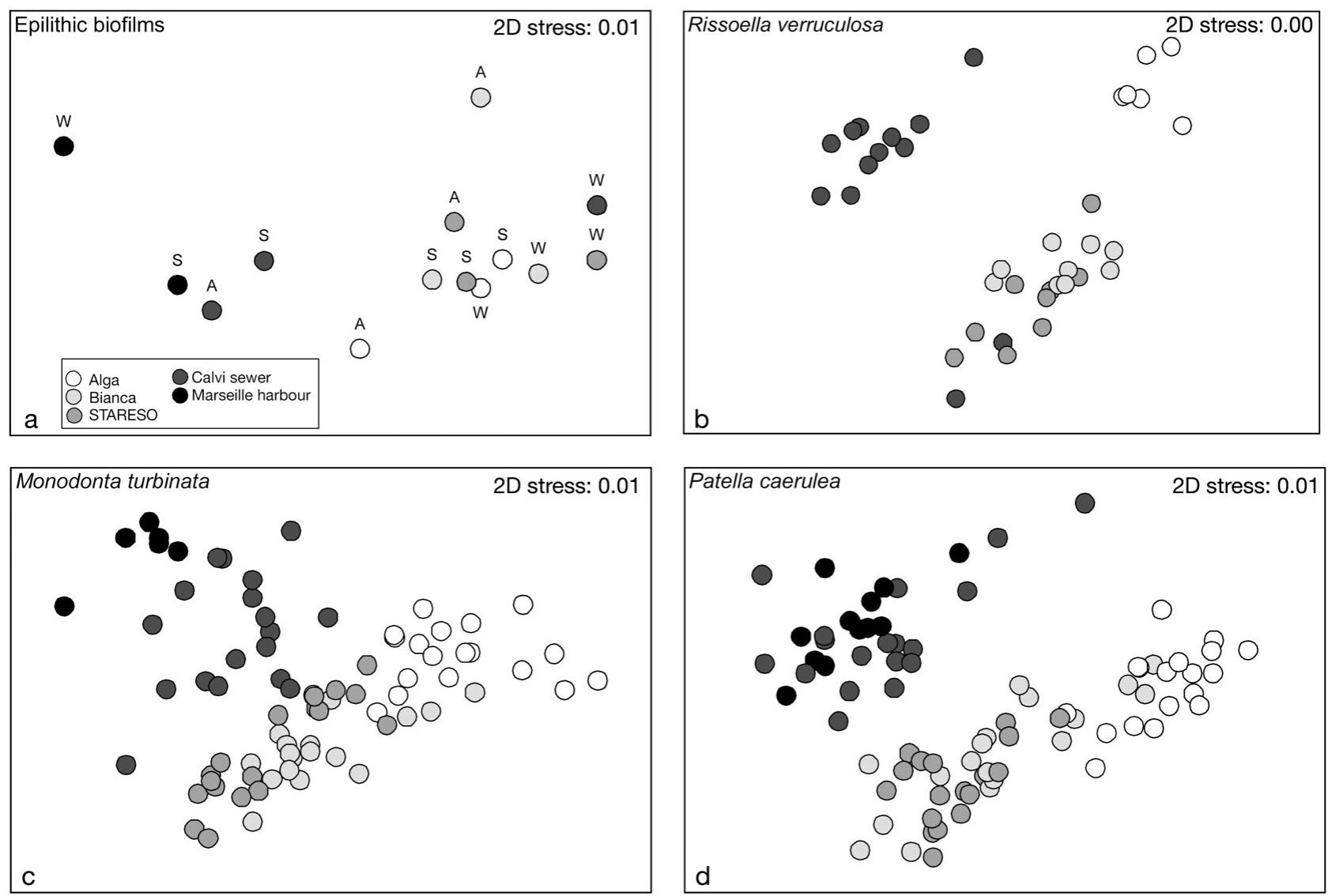

Fig. 2. nMDS ordinations of $\delta^{15} \mathrm{~N}$ and $\delta^{13} \mathrm{C}$ individual values from (a) epilithic biofilms, (b) Rissoella verruculosa, (c) Monodonta turbinata and (d) Patella caerulea over study time and at kilometre-scale. Graded shading shows the exposure of sites to nutrient enrichment: Alga (white), Bianca (light grey), STARESO (medium grey), Calvi sewer (dark grey), Marseille harbour (black). For epilithic biofilms, letters indicate the seasonal variability of values: (A) autumn, (W) winter and (S) summer

Table 2. Small-scale variability of $\delta^{15} \mathrm{~N}$ and $\delta^{13} \mathrm{C}$ values from Patella caerulea, Monodonta turbinata $(\mathrm{n}=6$, mean $\pm \mathrm{SD}$ in $\%$, coefficient of variation CV in \%) and epilithic biofilms collected along horizontal transects (1 to 4; see Fig. 1) (n = 1, in \%o except for 'biofilms overall (1 to 4)' mean $\pm \mathrm{SD}, \mathrm{CV} \%$ ) at Bianca and Calvi sewer in autumn. Gaps indicate no data available

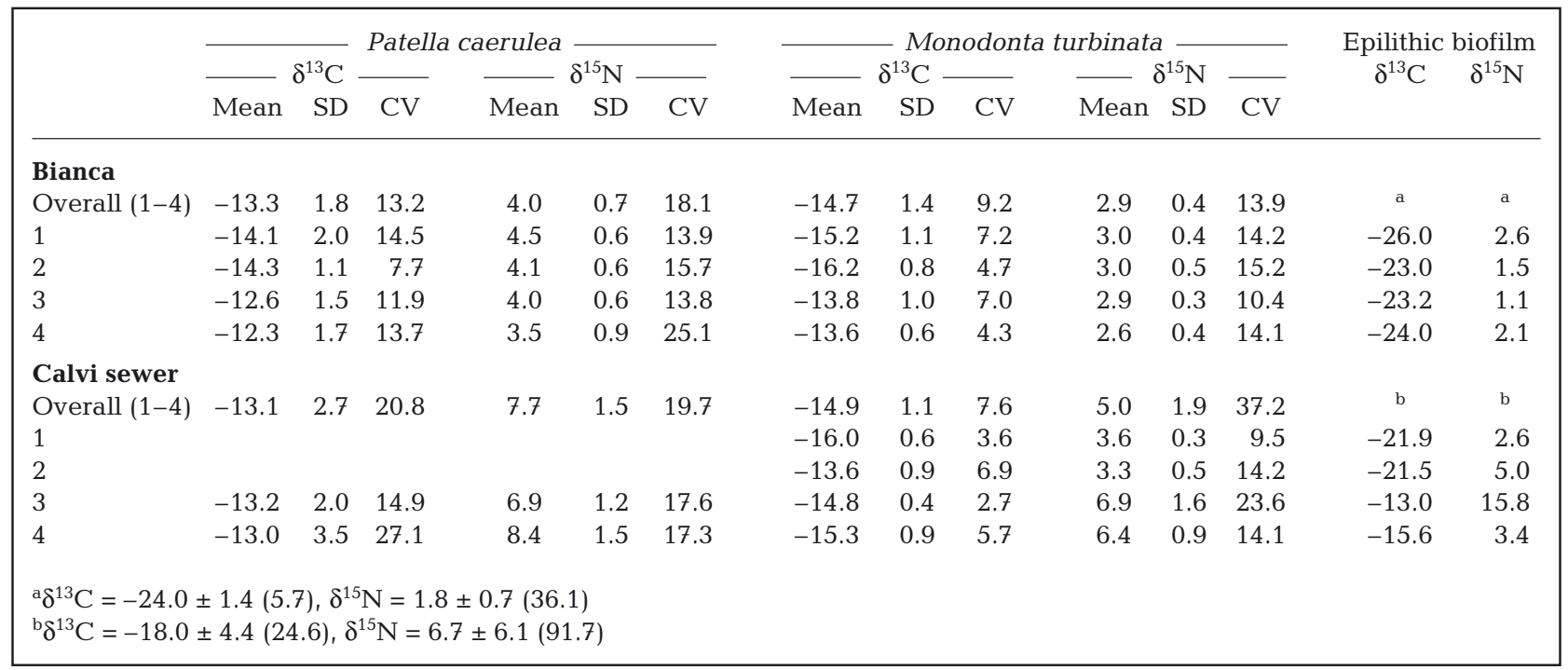


Table 3. C:N ratios (w/w) and nitrogen contents (\% dry wt) of epilithic biofilms between winter, summer and autumn and for Rissoella verruculosa in summer $($ mean $\pm \mathrm{SD})$. Gaps indicate no data available

\begin{tabular}{|lrrrrrrr|} 
& $\mathrm{n}$ & \multicolumn{2}{c}{ Winter } & \multicolumn{2}{c}{ Summer } & \multicolumn{2}{c|}{ Autumn } \\
& & $\mathrm{C}: \mathrm{N}$ & $\mathrm{N}$ & $\mathrm{C}: \mathrm{N}$ & $\mathrm{N}$ & $\mathrm{C}: \mathrm{N}$ & $\mathrm{N}$ \\
\hline Epilithic biofilm & & & & & & & \\
Alga & 1 & 7.8 & 5.4 & 10.0 & 3.0 & 12.3 & 1.8 \\
Bianca & 1 & 6.3 & 6.3 & 9.1 & 4.8 & 9.5 & 2.8 \\
Stareso & 1 & 7.1 & 4.7 & 10.7 & 1.6 & 10.7 & 2.6 \\
Calvi sewer & 1 & 5.5 & 7.6 & 9.7 & 3.7 & 14.3 & 1.4 \\
Marseille harbour & 1 & 9.2 & 2.5 & 11.7 & 3.3 & & \\
Rissoella verruculosa & & & & & & & \\
Alga & 6 & & & $30.5 \pm 1.1$ & $0.9 \pm 0.0$ & & \\
Bianca & 10 & & & $14.8 \pm 1.3$ & $2.1 \pm 0.2$ & & \\
Stareso & 9 & & & $14.0 \pm 1.8$ & $2.5 \pm 0.8$ & & \\
Calvi sewer & 13 & & & $19.8 \pm 1.6$ & $1.6 \pm 0.1$ & & \\
\hline
\end{tabular}
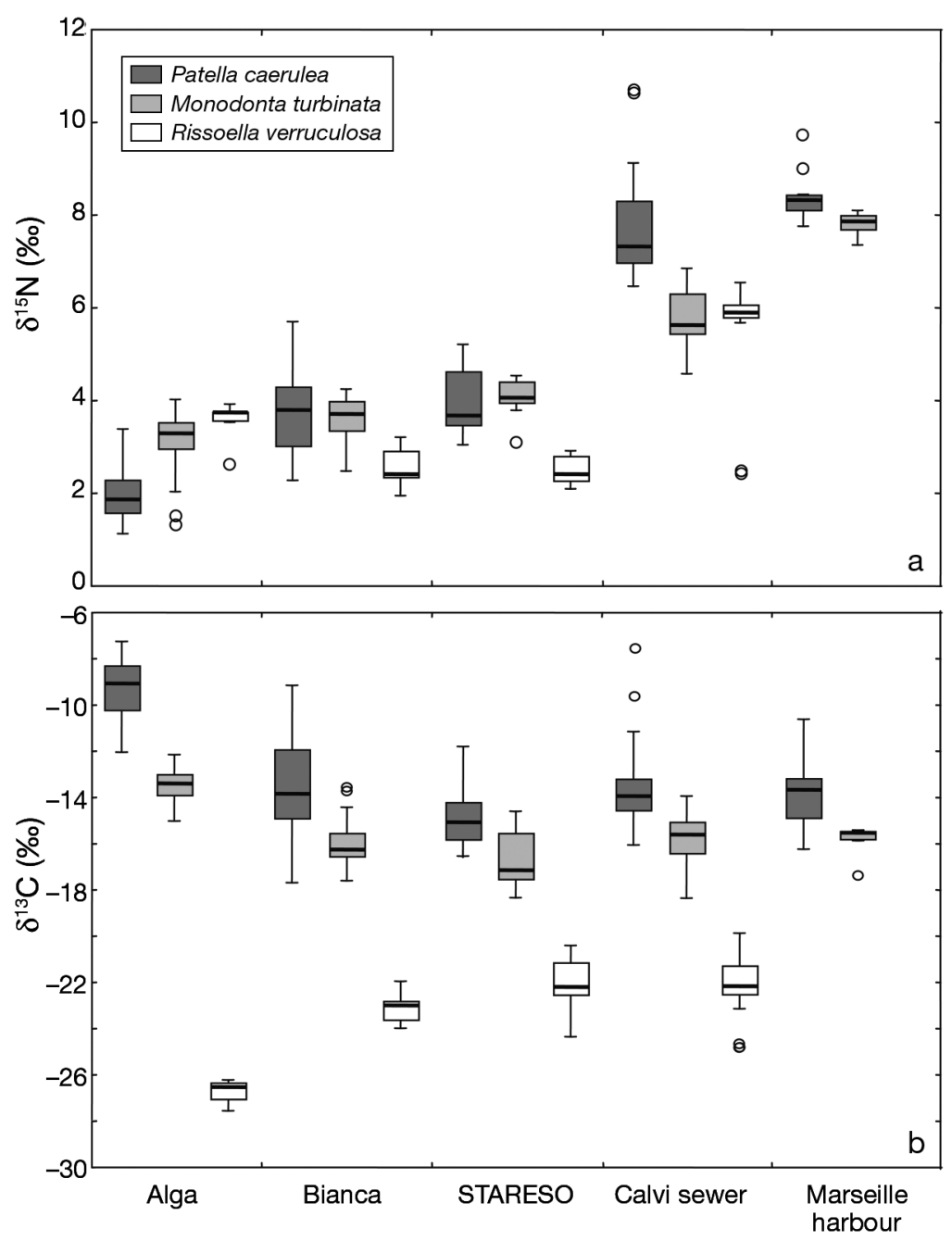

Fig. 3. Kilometre-scale (a) $\delta^{15} \mathrm{~N}$ and (b) $\delta^{13} \mathrm{C}$ values from Patella caerulea (dark grey), Monodonta turbinata (light grey) and Rissoella verruculosa (white; except for Marseille harbour) over study period. Thick horizontal lines indicate medians, boxes the interquartile ranges and whiskers mark the range of data excluding outliers (open circles, $>1.5 \times$ interquartile range) especially for Monodonta turbinata at Calvi sewer (Global $\mathrm{R}=0.65$, Tables 2 \& 4). Snails showed $\Delta^{15} \mathrm{~N}(3.6 \%)$ and $\Delta^{13} \mathrm{C}$ $(2.4 \%)$ ranges, which were comparable to the kilometre-scale ranges but occurred within distances of 30 to $60 \mathrm{~m}$ and lead to large between-points separation in the nMDS diagram $\left(\mathrm{R} \delta^{15} \mathrm{~N}=\right.$ 0.58, Fig. 4a). The overall $\delta^{15} \mathrm{~N}$ coefficients of variation were $37.2 \%$ at Calvi sewer as opposed to $13.9 \%$ at Bianca for M. turbinata. The $\delta^{15} \mathrm{~N}$ values for Patella caerulea did not show such discrepancy between points along the horizontal transect (Fig. 4b). For both species at Bianca, the main causes of small-scale isotopic variability were the $\delta^{13} \mathrm{C}$ values with $\Delta^{13} \mathrm{C}$ ranges of $2.0 \%$ for $M$. turbinata and $2.6 \%$ for $P$. caerulea over 30 to $60 \mathrm{~m}$ (Table 2). No particular trend appeared when comparing the coefficients of variation between kilometerscale and small-scale results.

\section{Intra- and interspecific variability in isotopic ratios}

A slight negative correlation between the shell length and the $\delta^{15} \mathrm{~N}$ values of Patella caerulea was found at STARESO $\left(\mathrm{r}^{2}=0.18, \mathrm{p}=0.03\right)$, while no significant difference was observed for the $\delta^{13} \mathrm{C}$ values $\left(\mathrm{r}^{2}=0.07\right)$. The main variability in $\delta^{15} \mathrm{~N}$ values was attributed to only few individuals belonging to the 15 to $20 \mathrm{~mm}$ class (Fig. 5a). The plot of $\delta^{15} \mathrm{~N}$ and $\delta^{13} \mathrm{C}$ individual values showed a strong negative relationship at a single sampling point for $P$. caerulea (STARESO, $\left.\mathrm{r}^{2}=0.55, \mathrm{p}=0.0001\right)$ and for both limpets $\left(r^{2}=0.48, p=0.0002\right)$ and snails $\left(\mathrm{r}^{2}=0.31, \mathrm{p}=0.004\right)$ over multiple sampling points at Bianca (Fig. 5b). Along this transect, the use of individual instead of mean $\delta^{15} \mathrm{~N}$ values revealed a large variability of results ranging from about 2.0 to $3.7 \%$ o for snails and to $5.7 \%$ for limpets. The occurrence of elevated $\delta^{15} \mathrm{~N}$ values was nevertheless lower than at Calvi sewer or Marseille harbour. We did not detect any differences in isotopic values that could be ascribed to the sex of individuals. 

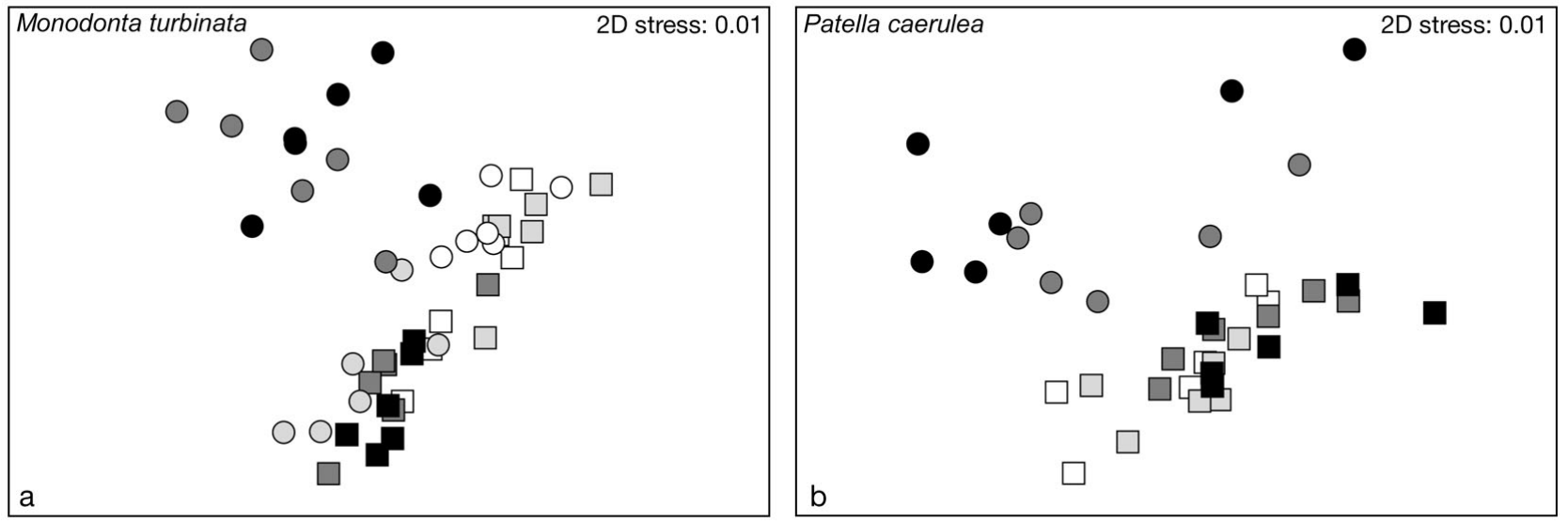

Fig. 4. nMDS ordinations of small-scale $\delta^{15} \mathrm{~N}$ and $\delta^{13} \mathrm{C}$ values from (a) Monodonta turbinata and (b) Patella caerulea at Bianca (squares) and Calvi sewer (circles) in autumn. Graded shading shows increasing distances between the points $30 \mathrm{~m}$ apart along the horizontal transects (Fig. 1): 1 (white), 2 (light grey), 3 (medium grey), 4 (black)

Although they provided the same overall isotopic patterns, differences occurred among gastropods, with Monodonta turbinata consistently showing more restricted ranges of isotopic values and an overall depletion in ${ }^{13} \mathrm{C}$ isotope compared to Patella caerulea. The

Table 4. Summary of ANOSIM R statistics computed for Patella caerulea, Monodonta turbinata and Rissoella verruculosa over the study period, and in autumn for small-scale data from the samples collected along the horizontal transects (Fig. 1). Global R: combined analysis of $\delta^{13} \mathrm{C}$ and $\delta^{15} \mathrm{~N}$. Significant differences are $\mathrm{p}<0.01$ except ns: not significant

\begin{tabular}{|lcccc|}
\hline & \multirow{2}{*}{ Seasonal } & \multirow{2}{*}{$\mathrm{km}$-scale } & \multicolumn{2}{c|}{ Small-scale } \\
\cline { 4 - 5 } & & & & \multicolumn{2}{c|}{ Calvi sewer } & Bianca \\
\hline Patella caerulea & & & & \\
Global R & 0.26 & 0.72 & $0.11 \mathrm{~ns}$ & $0.00 \mathrm{~ns}$ \\
$\mathrm{R} \delta^{13} \mathrm{C}$ & 0.15 & 0.41 & $0.00 \mathrm{~ns}$ & $0.01 \mathrm{~ns}$ \\
$\mathrm{R} \delta^{15} \mathrm{~N}$ & 0.20 & 0.76 & $0.07 \mathrm{~ns}$ & $0.01 \mathrm{~ns}$ \\
Monodonta turbinata & & & & \\
Global R & 0.30 & 0.78 & 0.65 & 0.24 \\
$\mathrm{R} \delta^{13} \mathrm{C}$ & 0.20 & 0.48 & 0.32 & 0.38 \\
$\mathrm{R} \delta^{15} \mathrm{~N}$ & 0.31 & 0.72 & 0.58 & \\
Rissoella verruculosa & & & & \\
Global R & & 0.66 & & \\
$\mathrm{R} \delta^{13} \mathrm{C}$ & & 0.42 & & \\
$\mathrm{R} \delta^{15} \mathrm{~N}$ & & 0.51 & & \\
\hline
\end{tabular}

use of ANOVA allowed detection of large differences in carbon isotopic compositions between snails and limpets $(\mathrm{p}<0.0001)$ but did not find significant differences in $\delta^{15} \mathrm{~N}(\mathrm{p}=0.62)$ or in Sites $\times$ Species interaction effects for either $\delta^{15} \mathrm{~N}(p=0.13)$ or $\delta^{13} \mathrm{C}$ values $(p=0.90)$.

The largest and more consistent interspecific differences in mean $\delta^{13} \mathrm{C}$ values were seen at Alga $\left(\mathrm{R} \delta^{13} \mathrm{C}=0.90\right.$, Table 6). Differences were marked for both isotopic ratios at other sites of the Revellata Bay area $(0.58>$ Global R > 0.73) and also emerged from smallscale data at Bianca (Global $\mathrm{R}=0.62$ ). The isotopic values of limpets consistently exhibited higher variability than those of snails, leading to some between- and within-sites overlap of values (Fig. 3). The coefficients of variation from $M$. turbinata were generally lower for the $\delta^{15} \mathrm{~N}$ values and consistently showed values for $\delta^{13} \mathrm{C}$ that were below $10 \%$ while those from $P$. caerulea frequently exceeded this value.

Table 5. Output of ANOSIM main pairwise comparisons of $\delta^{13} \mathrm{C}$ and $\delta^{15} \mathrm{~N}$ values for Patella caerulea, Monodonta turbinata (all seasons considered), and Rissoella verruculosa. Global R: combined analysis of $\delta^{13} \mathrm{C}$ and $\delta^{15} \mathrm{~N}$. Significant differences are $\mathrm{p}<0.01$ except ${ }^{*} \mathrm{p}<0.05$, ns: not significant. Gaps indicate no data available

\begin{tabular}{|c|c|c|c|c|c|c|c|c|c|}
\hline & \multicolumn{3}{|c|}{ Patella caerulea } & \multicolumn{3}{|c|}{ Monodonta turbinata } & \multicolumn{3}{|c|}{ Rissoella verruculosa } \\
\hline & Global R & $\mathrm{R} \delta^{13} \mathrm{C}$ & $\mathrm{R} \delta^{15} \mathrm{~N}$ & Global R & $\mathrm{R} \delta^{3} \mathrm{C}$ & $\mathrm{R} \delta^{15} \mathrm{~N}$ & Global R & $\mathrm{R} \delta^{13} \mathrm{C}$ & $\mathrm{R} \delta^{15} \mathrm{~N}$ \\
\hline Alga vs. Bianca & 0.67 & 0.63 & 0.53 & 0.78 & 0.79 & 0.45 & 1.00 & 1.00 & 0.66 \\
\hline Bianca vs. STARESO & $0.15^{*}$ & $0.15^{*}$ & $0.16^{*}$ & 0.43 & 0.30 & 0.37 & $0.17^{*}$ & $0.17^{*}$ & $0.00 \mathrm{~ns}$ \\
\hline STARESO vs. Calvi sewer & 0.80 & $0.17^{*}$ & 0.95 & 0.73 & 0.33 & 0.89 & 0.61 & $0.00 \mathrm{~ns}$ & 0.60 \\
\hline Calvi sewer vs. Marseille harbour & $0.14^{*}$ & $0.00 \mathrm{~ns}$ & 0.46 & 0.83 & $0.06 \mathrm{~ns}$ & 1.00 & & & \\
\hline
\end{tabular}




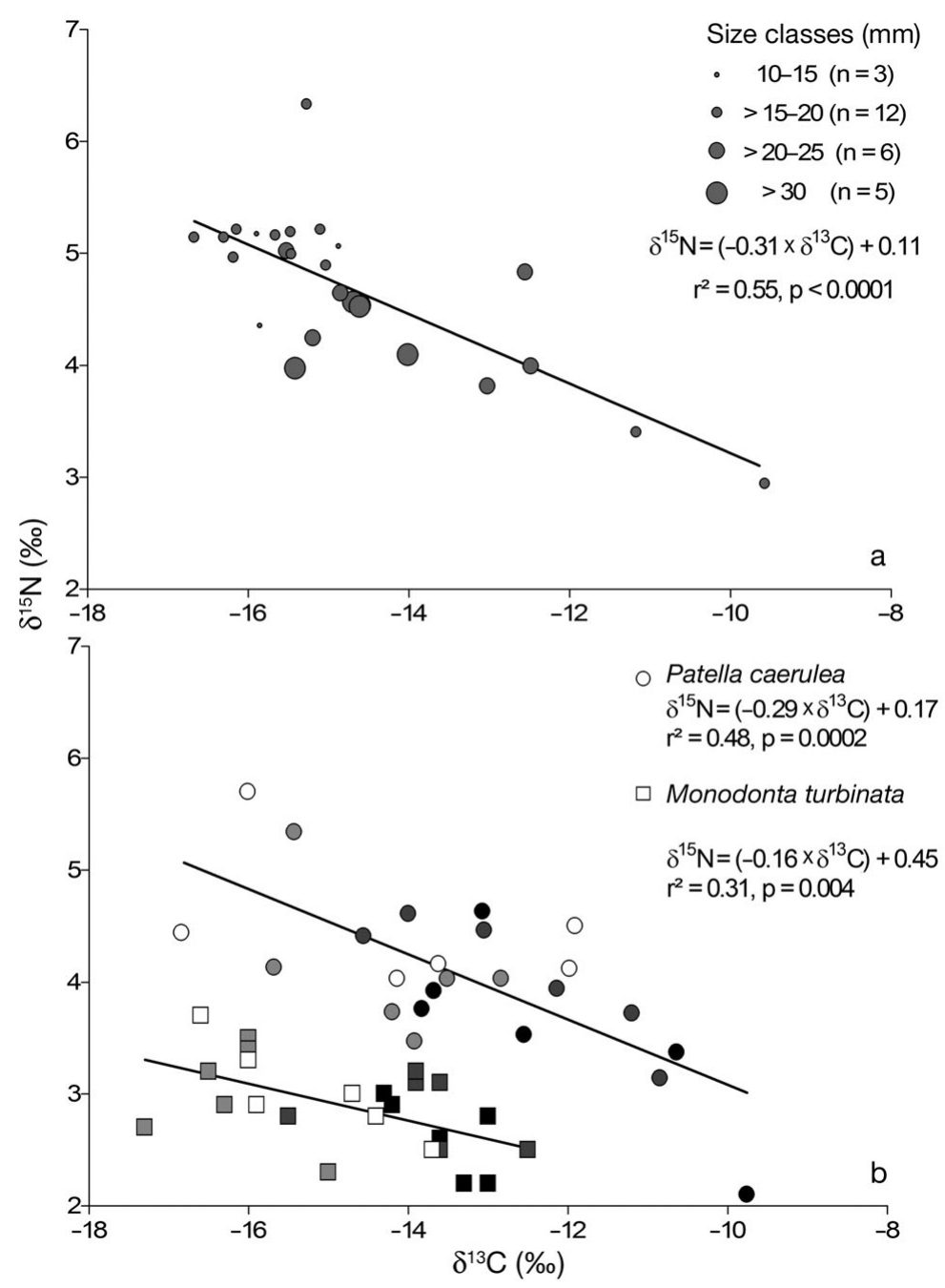

Fig. 5. Relationships between $\delta^{15} \mathrm{~N}$ and $\delta^{13} \mathrm{C}$ values for size classes (in mm) of Patella caerulea individuals from (a) STARESO and (b) for small-scale values from $P$. caerulea and Monodonta turbinata at Bianca $(n=6)$ in autumn. Shading in (b) refers to increasing distances between the points $30 \mathrm{~m}$ apart along the horizontal transects (Fig. 1): 1 (white), 2 (light grey), 3 (medium grey), 4 (black)

Table 6. Per-site output of ANOSIM showing interspecific differences in $\delta^{13} \mathrm{C}$ and $\delta^{15} \mathrm{~N}$ values between Patella caerulea and Monodonta turbinata. The small-scale results (points $30 \mathrm{~m}$ apart along the horizontal transects, Fig. 1) from Bianca and Calvi sewer are also shown. Global R: combined analysis of $\delta^{13} \mathrm{C}$ and $\delta^{15} \mathrm{~N}$. Significant differences are $\mathrm{p}<0.01$ except ${ }^{*} \mathrm{p}<0.05$, ns: not significant

\begin{tabular}{|c|c|c|c|}
\hline & \multicolumn{3}{|c|}{ Patella caerulea vs. Monodonta turbinata } \\
\hline & Global R & $\mathrm{R} \delta^{13} \mathrm{C}$ & $\mathrm{R} \delta^{15} \mathrm{~N}$ \\
\hline Alga & 0.76 & 0.90 & 0.31 \\
\hline Bianca & 0.58 & 0.40 & 0.47 \\
\hline Stareso & 0.73 & 0.34 & 0.58 \\
\hline Calvi sewer & 0.70 & 0.29 & 0.70 \\
\hline Marseille harbour & 0.57 & $0.42^{*}$ & 0.33 \\
\hline Bianca 1-4 & 0.62 & $0.15^{*}$ & 0.56 \\
\hline Calvi sewer 3-4 & $0.20^{*}$ & $0.03 \mathrm{~ns}$ & $0.11 \mathrm{~ns}$ \\
\hline
\end{tabular}

\section{DISCUSSION}

The isotopic results from gastropods, macroalgae and biofilms exhibited large spatial variability at kilometre-scale. They consistently showed ${ }^{15} \mathrm{~N}$ enrichment at impacted sites compared to pristine ones, thus corroborating previous findings that stable nitrogen isotopes can be used as an environmental tracer in order to detect the influence of anthropogenically derived nutrients in coastal ecosystems (e.g. McClelland et al. 1997). Although biofilms showed a ${ }^{13} \mathrm{C}$ enrichment trend at impacted sites, the $\delta^{13} \mathrm{C}$ spatial patterns did not discriminate between the terrestrial ( -23 to $-30 \%$ for C3 plants) or marine ( -18 to $-24 \%$ for phytoplankton) origin of materials (Fry \& Sherr 1984).

\section{Indicators of anthropogenically derived nutrients}

Despite the scarcity of stable isotope measurements from natural epilithic biofilms, our overall low $\delta^{13} \mathrm{C}$ and $\delta^{15} \mathrm{~N}$ values were in accordance with experimental results obtained from artificial substrates in seawater (Staal et al. 2007) and freshwater (MacLeod \& Barton 1998, Hill \& Middleton 2006). Most of our $\delta^{15} \mathrm{~N}$ values were typical of primary producers from the Mediterranean Sea. This can be explained by the occurrence of the lower $\delta^{15} \mathrm{~N}$ values of DIN in this part of the world compared to more eutrophic areas (e.g. Krom et al. 2004). Epilithic biofilms tended to concomitantly exhibit some ${ }^{13} \mathrm{C}$ - and ${ }^{15} \mathrm{~N}$ enriched values at impacted sites, suggesting that both the nature and the isotopic compositions of dissolved inorganic carbon (DIC) and nitrogen (DIN) sources available to microalgae were variable at the kilometrescale and, notably, according to the availability of anthropogenically derived nutrients (Costanzo et al. 2001, Vizzini et al. 2005). Rather than assigning a particular $\delta^{13} \mathrm{C}$ value to DIC originating from wastewater, we hypothesized that a supply of anthropogenic nutrients may have stimulated the growth of microalgae, leading to a low discrimination against both the ${ }^{13} \mathrm{C}$ isotope and the enriched ${ }^{15} \mathrm{NH}_{4}{ }^{+}$pool (Brutemark et al. 2009). Furthermore, as nutrient requirements and isotopic fractionation processes are taxa-specific, a proliferation of opportunistic nitrophilous taxa was possible 
at impacted sites (Wilmotte \& Demoulin 1988, Vuorio et al. 2006). For example, isotopic values from the heavily and steadily impacted Marseille harbour remained constant over time, as opposed to those from Calvi sewer where summer pulses of nutrients may have stimulated a shift in the composition of microflora. This seemed to show that, probably due to their high turnover rates (Burns \& Ryder 2001, Vadeboncoeur et al. 2003), biofilms respond rapidly in relation to fluctuations in $\delta^{15} \mathrm{~N}$ of nitrogen sources (i.e. caused by the influx of tourists in summer) and that they could be good indicators of seasonal changes in nutrient loads. The emergence of compound-specific stable isotope analyses will likely refine our knowledge of the taxonomic composition and metabolism of biofilms by targeting the isotopic composition of specific fractions (autotrophs, heterotrophs, detritus), which we were not able to dissociate in this study (e.g. Oakes et al. 2005).

In contrast to biofilms, the isotopic values of gastropods exhibited low seasonal variability, suggesting a slow turnover of muscle tissue over a period of several months (Lorrain et al. 2002). This is in agreement with feeding experiments conducted on the marsh periwinkle Littorina irrorata which showed half-life of a ${ }^{15} \mathrm{~N}$ label ranging from 99 to $231 \mathrm{~d}$ (turnover model from McIntyre \& Flecker 2006 applied to data from Kemp et al. 1990). The $\delta^{15} \mathrm{~N}$ values of gastropods reflected the exposure of sites to anthropogenic impact, showing that they were likely feeding from a food web for which the $\delta^{15} \mathrm{~N}$ baseline was set higher at impacted sites compared to pristine ones. The $\delta^{15} \mathrm{~N}$ baseline concept refers to the time-integrated signal provided by primary consumers which allows the characterization of the base of food webs (Cabana \& Rasmussen 1996, Vander Zanden \& Rasmussen 1999). The use of microphagous gastropods exhibiting plasticity in their feeding behaviour (Hawkins \& Hartnoll 1983) may have increased the probability of assimilating material that incorporated ${ }^{15} \mathrm{~N}$ from human effluents. Moreover, as an indirect effect of nutrient enrichment, the abundance of small animals (ostracods, copepods, small molluscs) was likely high in relation to that of microalgal biomass (Gil et al. 2006, Armitage \& Fourqurean 2009). Small animals are frequently observed in the gut of limpets and snails (Hill \& Hawkins 1991, Vermeulen 2006, Camus et al. 2008), and and a recent study provides an insight into the assimilation of such food items by chitons and key-hole limpets (Camus et al. 2009).

Conversely, the lower $\delta^{15} \mathrm{~N}$ values from control sites and especially at Alga were more typical of Mediterranean first consumers (Lepoint et al. 2000). The concomitantly ${ }^{13} \mathrm{C}$-enriched and ${ }^{15} \mathrm{~N}$-depleted values from Alga undoubtedly show that both the DIC and DIN pools and the composition of food sources available to grazers differed in comparison with other sites. Furthermore, Alga receives large amounts of litter deposits from the adjacent Posidonia oceanica seagrass meadow. Although sampling was performed away from the deposition area, the degradation of litter was likely to influence the isotopic values of inorganic pools used by primary producers. The assimilation by gastropods of some pieces of decaying leaves with $\delta^{13} \mathrm{C}$ and $\delta^{15} \mathrm{~N}$ values of about -13.0 and $1.3 \%$, respectively, as well as their fouling organisms (bacteria, fungi, blue-green algae, diatoms) was considered possible (Kurata et al. 2001, Sturaro et al. 2010).

The fact that $\mathrm{N}$ contents and isotopic values of Rissoella verruculosa at Alga were set apart from those of other locations also supports the idea that Alga is a distinct area as regards DIC and DIN fluxes. However, the isotopic pattern of $R$. verruculosa was inconsistent with that of gastropods since values for this species at Alga were ${ }^{13} \mathrm{C}$-depleted and ${ }^{15} \mathrm{~N}$-enriched compared to those from STARESO and Bianca. The turnover rate of $R$. verruculosa, likley being intermediate between that of biofilms and gastropods, may be responsible for providing a different isotopic signal. Nevertheless, macroalgae exhibited maximum $\Delta^{15} \mathrm{~N}$ ranges similar to Monodonta turbinata between Calvi sewer and Bian$\mathrm{ca}$, showing that, despite its seasonal occurrence, $R$. verruculosa provides a reliable snapshot for detecting the influence of sewage.

Surprisingly, in Revellata Bay, the $\Delta^{15} \mathrm{~N}$ values between impacted and control sites were far higher and also more consistent compared to those previously measured in other Mediterranean coastal open water and non-estuarine areas (Vizzini \& Mazzola 2006, Lassauque et al. 2010). In fact, our $\Delta^{15} \mathrm{~N}$ ranges for gastropods at Revellata Bay fell within those reported from areas receiving high nitrogen loads in Mediterranean lagoons (Carlier et al. 2008) and worldwide, in both freshwater and marine systems (Cabana \& Rasmussen 1996, Riera et al. 2000, McKinney et al. 2001, 2002, Tewfik et al. 2005) (Table 7). With respect to the relatively low nutrient loads in the Revellata Bay, this unexpectedly strong signal seemed to show a greater than previously thought influence of sewage and/or highlighted the importance of even occasional supplies of anthropogenic nitrogen in a naturally nutrient-limited system.

The small-scale data provided qualifed support for these conclusions and the first evidence of large $\delta^{13} \mathrm{C}$ and $\delta^{15} \mathrm{~N}$ variability at a scale of tens of metres within a single, apparently homogeneous habitat (see Guest et al. 2004 for small-scale inter-habitat $\delta^{13} \mathrm{C}$ variability). At Calvi sewer, samples of biofilms and Monodonta turbinata taken from points $30 \mathrm{~m}$ apart exhibited ranges of $\delta^{15} \mathrm{~N}$ values that were respectively higher 
Table 7. Reported maximum ranges of $\Delta^{15} \mathrm{~N}$ values (impacted - control mean values in \%o) among bivalves and gastropods. Pollution sources refer to wastewater discharge $(\mathrm{w})$ and agricultural fertilizers (af). Functional feeding groups are: bivalve suspension (Bv-Sf) and deposit feeders (Bv-Df), gastropod deposit feeders (G-Df) and grazers (G-g)

\begin{tabular}{|lcccll|}
\hline Organisms & $\begin{array}{c}\text { Feeding } \\
\text { groups }\end{array}$ & $\Delta^{15} \mathrm{~N}$ & Pollution & Locality & Source \\
\hline Elliptio spp. & Bv-Sf & 7.7 & w, af & Lakes, USA & McKinney et al. (2002) \\
Geukensia demissa & Bv-Sf & 2.7 & w, af & Semi-enclosed estuaries, USA & McKinney et al. (2001) \\
Abra ovata & Bv-Df & 10.6 & w, af & Coastal lagoons, NW Mediterranean & Carlier et al. (2008) \\
Strombus gigas & G-Df & 4.2 & w & Coastal, Dominican Republic & Tewfik et al. (2005) \\
Strombus costatus & G-Df & 5.5 & w & Coastal, Dominican Republic & Tewfik et al. (2005) \\
Pinna carnea & Bv-Sf & 2.9 & w & Coastal, Dominican Republic & Tewfik et al. (2005) \\
Crassostrea gigas & Bv-Sf & 9.5 & w, af & Estuaries, NW Europe & Riera et al. (2000) \\
Littorina littorea & G-g & 7.5 & w, af & Estuaries, NW Europe & Riera et al. (2000) \\
Littorina saxatilis & G-g & 5.1 & w, af & Estuaries, NW Europe & Riera et al. (2000) \\
Mussels & Bv-Sf & 7.8 & w & Lakes, Quebec & Cabana \& Rasmussen (1996) \\
Patella caerulea & G-g & 6.7 & w & Coastal, Mediterranean & Present study \\
Monodonta turbinata & G-g & 4.5 & w & Coastal, Mediterranean & \\
\hline
\end{tabular}

than and close to those found between impacted and control sites (i.e. at kilometre-scale). This could be interpreted as showing an uneven influence of sewage along the shore due to the effects of diffuse sources of wastewater and the mixing between naturally occurring DIN and the ${ }^{15} \mathrm{~N}$ enriched pools coming from the main sewage outfall. Thus, it appears that establishing a $\delta^{15} \mathrm{~N}$ baseline from a single sampling point is controversial because it does not integrate the whole habitat signal. For biofilms and gastropods, such sampling may lead to either a failure in detecting wastewater influence or an over-estimation of its spatial extent (Bishop et al. 2002).

\section{Potential confounding effects in gastropods}

Gastropods can be considered as reliable indicators, providing a time-integrated but spatially uneven signal of anthropogenically derived nitrogen. The interand intra-specific variability in isotopic values could lead to some additional confounding effects due to species particular morphological and behavioural features. For example, the occurrence of large isotopic variances like those observed for Patella caerulea may limit the reliability of this species as a bioindicator of the exposure of sites to urban effluents. The response of snails was closer to the pattern of graduated exposure of sites to anthropogenic impact, exhibiting the greatest difference between the heavily impacted Marseille harbour and Calvi sewer and a ${ }^{15} \mathrm{~N}$-enrichment signal at the moderately impacted STARESO site. Monodonta turbinata individuals also consistently showed more depleted ${ }^{13} \mathrm{C}$ values compared to $P$. caerulea, suggesting differences in diet composition between these coexisting species. Although gastropods likely experience specific isotopic fractionation while processing food into their tissues (Bearhop et al. 2004), we assumed that the existence of distinct radular apparatus was a good explanation for interspecific differences in isotopic composition. Whereas the rhipidoglossan radula of $M$. turbinata brushes substrate, the minerally hardened teeth of the docoglossan radula of P. caerulea act as a rasp (Hawkins \& Hartnoll 1983). Therefore, as supported by their high isotopic variances, $P$. caerulea individuals could have relied on a broader range of food items (endolithic and endobiotic materials) than $M$. turbinata (Della Santina et al. 1993). The $\delta^{13} \mathrm{C}$ mismatch between biofilms and gastropods seemed to indicate that these generalist grazers did not, as previously thought, rely exclusively on biofilms as a food source (Hawkins \& Hartnoll 1983). The elucidation of these gastropods' diet would require detailed gut content analyses and further isotopic analyses from several other potential food sources (e.g. Kurata et al. 2001), which is beyond the scope of our study.

Commonly reported reasons for intra-population isotopic variance refer to physiological processes that vary according to size (or age), sex, developmental stages, and nutritional states of consumers (Adams \& Sterner 2000, Bearhop et al. 2004). Our results for limpets did not show strong evidence of size-related isotopic variability, even though the time required for isotopic equilibration (i.e. tissue replacement following a shift in diet composition) in small individuals is thought to be shorter than for larger ones (Sweeting et al. 2005).

The strong negative relationship found between the $\delta^{13} \mathrm{C}$ and $\delta^{15} \mathrm{~N}$ values from gastropods provided evidence for alternative explanations, other than size, for the isotopic variance found in this study. A similar isotopic pattern was previously described for some miscellaneous taxonomic groups of primary consumers and was attributed to the typical depth-related iso- 
topic values of primary producers (i.e. particular growth conditions) reflected in consumers' tissues (Vander Zanden \& Rasmussen 1999). Here, we reported such relationships within a single habitat and for single species of first consumers. We suggest that some patch-specific conditions, where available food varied in taxonomic composition, physiological state and nutritional value, led to inter- and intra-specific variability in isotopic composition (Lancaster \& Waldron 2001). Indeed, due to their low mobility and their specific foraging behaviour (limpets' homing vs. snails roaming, with no fixed resting site), the selected gastropods presumably relied on local resources produced in distinct microhabitats (Hawkins \& Hartnoll 1983, Hutchinson et al. 2007). A kind of gardening is even thought to occur among these species as the mucus they produce was recognised as a suitable medium for bacterial activity enhancing the growth of microalgae (Peduzzi \& Herndl 1991, Johnson et al. 2008).

\section{CONCLUSIONS}

The nitrogen stable isotope analyses applied to gastropods, macroalgae and epilithic biofilms highlighted their good sensitivity as indicators of the biological availability of anthropogenically derived nitrogen. Bioindicators exhibited different time-dependent responses to nutrient enrichment. Epilithic biofilms provided a short-term signal suggesting the influence of nutrient pulses during the tourist season. Their use in the early detection of wastewater disturbance is promising but requires further investigation, especially as regards their $\delta^{13} \mathrm{C}$ response at impacted sites, their composition and the mechanisms involved in the patchiness process. Although satisfactory, the signal delivered by the macroalga Rissoella verruculosa was less reliable compared to that of gastropods. Limpets and snails exhibited a time-integrated signal for several months, suggesting that 1 annual sampling campaign should be sufficient to determine the anthropogenic impact. We consider that Monodonta turbinata delivered the most suitable signal because mean values were associated with low variance and the discrimination between sites best mirrored the graduated exposure to anthropogenic impact. The large variability of our $\delta^{15} \mathrm{~N}$ baseline along small-scale transects (tens of metres) warned against drawing general conclusions from a pollution signal on only one sampling scale, especially when low-mobility invertebrate grazers are selected as potential bioindicators. This must be taken into account in future studies dealing with the assessment of anthropogenic impact and the understanding of food web functioning.
Acknowledgements. We thank R. Biondo and STARESO research station staff for field and laboratory assistance, and Professors V. Demoulin and P. Dauby, Drs. M. Poulicek, G. Quinn (CAMbio, Ireland) and anonymous referees for their critical comments on this work. We are grateful to J. Richir and L. Michel for statistical advice. This study was funded by the ARC-Rapid Assessment for the marine Coastal Environment 05/10-333, by the FRS-FNRS (Belgian National Fund for Scientific Research) FRFC 2.4.502.08.F and the French Belgian community. S.V. is funded by a PhD grant from the ARCRACE and G.L. is a Research Associate FRS-FNRS. This publication is MARE number 199.

\section{LITERATURE CITED}

Adams TS, Sterner RW (2000) The effect of dietary nitrogen content on trophic level ${ }^{15} \mathrm{~N}$ enrichment. Limnol Oceanogr 45:601-607

Armitage AR, Fourqurean JW (2009) Stable isotopes reveal complex changes in trophic relationships following nutrient addition in a coastal marine ecosystem. Estuar Coasts 32:1152-1164

Bearhop S, Adams CE, Waldron S, Fuller RA, MacLeod H (2004) Determining trophic niche width: a novel approach using stable isotope analysis. J Anim Ecol 73:1007-1012

> Bishop MJ, Underwood AJ, Archambault P (2002) Sewage and environmental impacts on rocky shores: necessity of identifying relevant spatial scales. Mar Ecol Prog Ser 236: 121-128

Brutemark A, Lindehoff E, Granéli E, Granéli W (2009) Carbon isotope signature variability among cultured microalgae: influence of species, nutrients and growth. J Exp Mar Biol Ecol 372:98-105

Burns A, Ryder DS (2001) Potential for biofilms as biological indicators in Australian riverine systems. Ecol Manag Restor 2:53-64

Cabana G, Rasmussen JB (1996) Comparison of aquatic food chains using nitrogen isotopes. Proc Natl Acad Sci USA 93:10844-10847

Camus PA, Daroch K, Opazo LF (2008) Potential for omnivory and apparent intraguild predation in rocky intertidal herbivore assemblages from northern Chile. Mar Ecol Prog Ser 361:35-45

> Camus PA, Cid YY, Cisterna L, Cáceres CW (2009) Consumption and digestion of animal food by rocky intertidal herbivores: an evaluation of digestive flexibility and omnivory in three grazing species. Lat Am J Aquat Res 37:191-197

Carballo JL, Naranjo SA, García-Gómez JC (1996) Use of sponges as stress indicators in marine ecosystems at Algeciras Bay (southern Iberian Peninsula). Mar Ecol Prog Ser 135:109-122

Carlier A, Riera P, Amouroux JM, Bodiou JY, Desmalades M, Grémare A (2008) Food web structure of two Mediterranean lagoons under varying degree of eutrophication. J Sea Res 60:264-275

Clarke KR, Gorley RN (2006) PRIMER v6: user manual/tutorial. PRIMER-E, Plymouth

Cloern JE (2001) Our evolving conceptual model of the coastal eutrophication problem. Mar Ecol Prog Ser 210: 223-253

Costanzo SD, O'Donohue MJ, Dennison WC, Loneragan NR, Thomas M (2001) A new approach for detecting and mapping sewage impacts. Mar Pollut Bull 42:149-156

Crothers JH (1994) Student investigations on the population structure of the common topshell, Monodonta lineata, on The Gore, Somerset. Field Stud 8:337-355 
Della-Santina P, Sonni C, Sartoni G, Chelazzi G (1993) Food availability and diet composition of three coexisting Mediterranean limpets (Patella spp.). Mar Biol 116:87-95

DeNiro MJ, Epstein S (1978) Influence of diet on the distribution of carbon isotopes in animals. Geochim Cosmochim Acta 42:495-506

Dytham C (2003) Choosing and using statistics: a biologist's guide. Blackwell, Berlin

Fry B, Sherr E (1984) $\delta^{13} \mathrm{C}$ measurements as indicators of carbon flow in marine and freshwater ecosystems. Contrib Mar Sci 27:13-47

> Gil M, Armitage AR, Fourqurean JW (2006) Nutrient impacts on epifaunal density and species composition in a subtropical seagrass bed. Hydrobiologia 569:437-447

Guest MA, Connolly RM, Loneragan NR (2004) Carbon movement and assimilation by invertebrates in estuarine habitats at a scale of metres. Mar Ecol Prog Ser 278:27-34

Hawkins SJ, Hartnoll RG (1983) Grazing of intertidal algae by marine invertebrates. Oceanogr Mar Biol Annu Rev 21: 195-282

> Hedges JI, Stern JH (1984) Carbon and nitrogen determinations of carbonate-containing solids. Limnol Oceanogr 29: 657-663

Hill AS, Hawkins S (1991) Seasonal and spatial variation of epilithic microalgal distribution and abundance and its ingestion by Patella vulgata on a moderately exposed rocky shore. J Mar Biol Assoc UK 71:403-423

Hill WR, Middleton RG (2006) Changes in carbon stable isotope ratios during periphyton development. Limnol Oceanogr 51:2360-2369

Hutchinson N, Davies MS, Ng JSS, Williams GA (2007) Trail following behaviour in relation to pedal mucus production in the intertidal gastropod Monodonta labio (Linnaeus). J Exp Mar Biol Ecol 349:313-322

Ifremer (Institut français de recherche pour l'exploitation de la mer) (2007) Synthèse de l'état de la contamination chimique du golfe de Marseille. Report No. R.INT.DOP/ LER-PAC/07-05. Ifremer, Paris

> Johnson MP, Hanley ME, Frost NJ, Mosley MWJ, Hawkins SJ (2008) The persistent spatial patchiness of limpet grazing. J Exp Mar Biol Ecol 365:136-141

Krom MD, Herut B, Mantoura RFC (2004) Nutrient budget for the eastern Mediterranean: implications for phosphorus limitation. Limnol Oceanogr 49:1582-1592

Kurata K, Minami H, Kikuchi E (2001) Stable isotope analysis of food sources for salt marsh snails. Mar Ecol Prog Ser 223:167-177

> Lancaster J, Waldron S (2001) Stable isotope values of lotic invertebrates: sources of variation, experimental design, and statistical interpretation. Limnol Oceanogr 46:723-730

Lassauque J, Lepoint G, Thibaut T, Francour P, Meinesz A (2010) Tracing sewage and natural freshwater input in a northwest Mediterranean bay: evidence obtained from isotopic ratios in marine organisms. Mar Pollut Bull 60: 843-851

Lepoint G, Nyssen F, Gobert S, Dauby P, Bouquegneau JM (2000) Relative impact of a seagrass bed and its adjacent epilithic algal community in consumer diets. Mar Biol 136:513-518

- Lorrain A, Paulet YM, Chauvaud L, Savoye N, Donval A, Saout C (2002) Differential $\delta^{13} \mathrm{C}$ and $\delta^{15} \mathrm{~N}$ signatures among scallop tissues: implications for ecology and physiology. J Exp Mar Biol Ecol 275:47-61

> MacLeod NA, Barton DR (1998) Effects of light intensity, water velocity, and species composition on carbon and nitrogen stable isotope ratios in periphyton. Can J Fish Aquat Sci 55:1919-1925
McClelland JW, Valiela I, Michener RH (1997) Nitrogenstable isotope signatures in estuarine food webs: a record of increasing urbanization in coastal watersheds. Limnol Oceanogr 42:930-937

McIntyre PB, Flecker AS (2006) Rapid turnover of tissue nitrogen of primary consumers in tropical freshwaters. Oecologia 148:12-21

McKinney RA, Nelson WG, Charpentier MA, Wigand C (2001) Ribbed mussel nitrogen isotope signatures reflect nitrogen sources in coastal salt marshes. Ecol Appl 11: 203-214

McKinney RA, Lake JL, Charpentier MA, Ryba S (2002) Using mussel isotope ratios to assess anthropogenic nitrogen inputs to freshwater ecosystems. Environ Monit Assess 74:167-192

Munda IM (1993) Changes and degradation of seaweed stands in the northern Adriatic. Hydrobiologia 260-261: 239-253

Nixon SW (1995) Coastal marine eutrophication: a definition, social causes, and future concerns. Ophelia 41:199-219

Oakes JM, Revill AT, Connolly RM, Blackburn SI (2005) Measuring carbon isotope ratios of microphytobenthos using compound-specific stable isotope analysis of phytol. Limnol Oceanogr Methods 3:511-519

Oehlmann J, Schulte-Oehlmann U (2003) Molluscs as bioindicators. In: Market BA, Breure AM, Zechmeister G (eds) Bioindicators and biomonitors. Elsevier Science Publishers, New York, NY, p 577-635

Orton JH, Southward AJ, Dodd JM (1956) Studies on the biology of limpets, II. the breeding of Patella vulgata L. in Britain. J Mar Biol Assoc UK 35:149-176

Peduzzi P, Herndl GJ (1991) Mucus trails in the rocky intertidal: a highly active microenvironment. Mar Ecol Prog Ser 75:267-274

Pérès JM, Picard J (1964) Nouveau manuel de bionomie benthique de la mer Méditerranée. Recl Trav Stn Mar Endoume 31:5-137

> Pinedo S, García M, Satta MP, De Torres M, Ballesteros E (2007) Rocky-shore communities as indicators of water quality: a case study in the northwestern Mediterranean. Mar Pollut Bull 55:126-135

Riera P, Stal LJ, Nieuwenhuize J (2000) Heavy $\delta^{15} \mathrm{~N}$ in intertidal benthic algae and invertebrates in the Scheldt estuary (the Netherlands): effect of river nitrogen inputs. Estuar Coast Shelf Sci 51:365-372

Segar DA, Phillips DJH, Stamnan E (1987) Strategies for longterm pollution monitoring of the coastal oceans. In: Boyle TP (ed) New approaches to monitoring aquatic ecosystems. American Society for Testing and Materials. Philadelphia, PA, p 12_27

Skliris N, Elkalay K, Goffart A, Frangoulis C, Hecq JH (2001) One-dimensional modelling of the plankton ecosystem of the north-western Corsican coastal area in relation to meteorological constraints. J Mar Syst 27:337-362

Soltan D, Verlaque M, Boudouresque CF, Francour P (2001) Changes in macroalgal communities in the vicinity of a Mediterranean sewage outfall after the setting up of a treatment plant. Mar Pollut Bull 42:59-70

Staal M, Thar R, Kühl M, Van Loosdrecht MCM, Wolf G, De Brouwer JFC, Rijstenbil JW (2007) Different carbon isotope fractionation patterns during the development of phototrophic freshwater and marine biofilms. Biogeosciences 4:613-626

> Steneck RS, Watling L (1982) Feeding capabilities and limitation of herbivorous molluscs: a functional group approach. Mar Biol 68:299-319

Sturaro N, Caut S, Gobert S, Bouquegneau JM, Lepoint G 
(2010) Trophic diversity of idoteids (Crustacea, Isopoda) inhabiting the Posidonia oceanica litter. Mar Biol 157:237-247

Sweeting CJ, Jennings S, Polunin NVC (2005) Variance in isotopic signatures as a descriptor of tissue turnover and degree of omnivory. Funct Ecol 19:777-784

Tewfik A, Rasmussen JB, McCann KS (2005) Anthropogenic enrichment alters a marine benthic food web. Ecology $86: 2726-2736$

UNEP/FAO/WHO (1996) Assessment of the state of eutrophication in the Mediterranean sea. MAP Technical Series No. 10. United Nations Environment Programme (UNEP), Athens

Vadeboncoeur Y, Jeppesen E, Vander Zanden MJ, Schierup HH, Christoffersen K, Lodge DM (2003) From Greenland to green lakes: cultural eutrophication and the loss of benthic energy pathways in lakes. Limnol Oceanogr 48: 1408-1418

Vander Zanden MJ, Rasmussen JB (1999) Primary consumer $\delta^{13} \mathrm{C}$ and $\delta^{15} \mathrm{~N}$ and the trophic position of aquatic consumers. Ecology 80:1395-1404

Velimirov B, Walenta-Simon M (1992) Seasonal changes in specific growth rates, production and biomass of a bacterial community in the water column above a Mediterranean seagrass system. Mar Ecol Prog Ser 80:237-248

Vermeulen S (2006) Utilisation des isotopes stables du C et du

Editorial responsibility: Pei-Yuan Qian,

Kowloon, Hong Kong SAR
$\mathrm{N}$ dans l'évaluation du potentiel de bioindicateur d'eutrophisation de deux gastéropodes herbivores de la zone médio-littorale en Baie de Calvi (Corse). MSc dissertation, University of Liège

- Vizzini S, Mazzola A (2006) The effects of anthropogenic organic matter inputs on stable carbon and nitrogen isotopes in organisms from different trophic levels in a southern Mediterranean coastal area. Sci Total Environ 368: 723-731

Vizzini S, Savona B, Chi TD, Mazzola A (2005) Spatial variability of stable carbon and nitrogen isotope ratios in a Mediterranean coastal lagoon. Hydrobiologia 550:73-82

$>$ Vuorio K, Meili M, Sarvala J (2006) Taxon-specific variation in the stable isotopic signatures $\left(\delta^{13} \mathrm{C}\right.$ and $\left.\delta^{15} \mathrm{~N}\right)$ of lake phytoplankton. Freshw Biol 51:807-822

> Waldron S, Tatner P, Jack I, Arnott C (2001) The impact of sewage discharge in a marine embayment: a stable isotope reconnaissance. Estuar Coast Shelf Sci 52:111-115

Wilmotte A, Demoulin V (1988) Studies of marine epiphytic algae, Calvi, Corsica. II. Seasonal variations in the populations of epiphytic blue-green algae in three harbours with different pollution loads. Br Phycol J 23:259-266

Zar J (1984) Biostatistical analysis, 2nd edn. Prentice-Hall, Englewood Cliffs, NJ

Submitted: June 15, 2010; Accepted: November 4, 2010 Proofs received from author(s): January 25, 2011 